\title{
ANOMALI PASAR MODAL MENUJU STUDI BEHAVIORAL ECONOMICS
}

\author{
Andreas Kiky \\ Bisnis Manajemen, Universitas Pradita, Indonesia \\ andreas.kiky@pradita.ac.id \\ Diterima 11 Februari 2020 \\ Disetujui 7 April 2020
}

\begin{abstract}
This research examine market anomali that used to be found in capital market. There are 3 (three) common market anomalies that observed by financial researcher, holiday effect (in this case Lebaran Effect), January effect and Monday effect. The goal in this empirical study is to confirm and examine these anomalies on consumer goods firms. One of most common misleading statement that would like to be argued by this research is on Lebaran Season; most likely consumer goods stocks would be the most wanted and highest return. Dummy variables are applied in research model to test research hypothesis regarding to this issue. Research models are analyzed using OLS approach and the result is indeed finding some anomali in Lebaran, January and Monday Effect. But the result from adjusted $R 2$ is very low $(<1 \%)$ which implies that explanatory power of event to abnormal return is need a critic and improvement. Further result from loss aversion theory confirms that most of Indonesian Citizen play save strategy under sure loss condition.
\end{abstract}

Keywords: Capital Market Anomali, EMH, Lebaran Effect, January Effect, Monday Effect, Behaviour Economics

\section{PENDAHULUAN}

\subsection{Latar Belakang Penelitian}

Dalam literatur keuangan, metode penilaian aset klasik seperti CAPM, APT, dan Multifactor Model mendapat tantangan dari studi empiris. Studi empiris dilakukan untuk mengecek kebenaran model keuangan yang dibangun atas dasar rasionalitas dari investor atas risiko. Akan tetapi dalam perkembangannya tidaklah mudah untuk melakukan hal tersebut, karena pada akhirnya pembuktian empiris hanya menimbulkan perdebatan akademisi keuangan yang tidak ada akhirnya. Dari berbagai riset terkait pembuktian penilaian aset (asset pricing) dengan pendekatan statistik, yakni metode regresi dan berbagai metode time series yang sangat sophisticated akhirnya berakhir dengan hasil yang tidak konsisten. Dalam perkembangannya, gagasan akan riset anomali pasar diangkat sebagai kajian empiris untuk menilai kecocokan teori dengan fakta di lapangan. Seringkali dalam ilmu keuangan, penelitian empiris mengenai pasar modal sendiri saling memperdebatkan satu sama lain. Selain banyaknya dukungan yang ditemukan pada model empiris tersebut, ternyata banyak juga sanggahan terhadap model yang sama jika data dianalisis dari perspektif yang berbeda. Jika memang model keuangan tersebut akurat, maka tidak akan terjadi anomali pasar seperti January effect, Lebaran Effect, ataupun Monday Effect. Timbul sebuah pertanyaan yakni dalam penyusunan model keuangan, apakah model tersebut memang benar dan cocok dengan perilaku manusia (investor)? Model tersebut pada dasarnya disusun atas dasar manusia yang rasional dan umumnya menghindari risiko. Jikapun manusia tersebut mendekati risiko 
(mencintai risiko) maka tentunya secara economics harusnya manusia membandingkan hasil yang diterima dan kerugian yang mungkin terjadi. Temuan mengenai anomali pasar sendiri bukanlah sesuatu yang baru. (Thaler R. H., Anomalies; The January Effect, 1987) menemukan bahwa return saham terkadang memiliki beberapa pola tertentu dan terjadi pada bulan tertentu, yakni Januari. Untuk fenomena yang terjadi di Indonesia (Aryanto, 2006) dan (Febrianto, 2015) menemukan pergerakan anomali pada seasonal effect menjelang lebaran.

Akan tetapi masalah terbesarnya adalah seringkali manusia berperilaku tidak rasional. Hal ini yang membuka sebuah cabang ilmu baru keuangan dengan mempertimbangkan pengambilan keputusan dan bagaimana manusia membuat keputusan dalam kondisi yang tidak pasti. Contoh salah satu dari fenomena ini adalah cashew phenomena. Fenomena ini diperkenalkan oleh Thaler seorang professor bidang behavior economics ketika mereka hendak menyantap hidangan makan malam yang masih belum siap. Sambil menunggu hidangan utama, mereka menunggu sambil mengambil cemilan kacang cashew yang berakibat pada habisnya 1 toples kacang tersebut. Takut cemilan tersebut mengurangi selera makan mereka, pada akhirnya Profesor Thaler menyingkirkan toples tambahan kacang tersebut dan semua bersyukur karena kacang itu tidak merusak selera makan mereka. Padahal dari perspektif ekonomi, jika memang mereka ingin menyantap hidangan utama, mereka tidak akan makan kacang cashew tidak berhentihenti. Jika mereka berperilaku demikian maka artinya mereka lebih menyukai (valued) kacang tersebut dibandingkan dengan hidangan utama (Thaler R. H., Misbehaving. The Making of Behavioral Economics, 2016).

Fenomena sederhana di atas menjadi trigger lebih lanjut bagaimana Thaler membahas perilaku irrasional dari manusia. Thaler berargumen bahwa manusia tidak sepenuhnya econs yang berarti selalu berperilaku rasional serta efisien. Dalam risetnya dugaan terhadap anomali pasar sendiri telah dikaji dalam observasi (Thaler R. H., Anomalies; The January Effect, 1987). Ditemukan pada berbagai wilayah atau pasar modal di berbagai belahan dunia, return cenderung tinggi pada bulan Januari. Akibatnya dampak seasonal dari kondisi ini membuka sebuah peluang bagi investor untuk mengambil keuntungan dari pola tersebut. Akan tetapi tentunya dalam diskusi, Thaler menyatakan dalam aplikasinya masih sangat sulit untuk diterapkan karena adanya perhitungan pajak dan biaya transaksi yang bisa jadi membuat keuntungan tersebut berkurang.

Fenomena keperilakuan dalam ilmu ekonomi termasuk di dalamnya perilaku irasional ini sebenarnya tidak lepas pengamatan peneliti ketika ilmu ekonomi itu sendiri digagas. Salah satu bahasan paling pertama terkait dengan temuan ini adalah dikenal dengan the impatience theory of interest. Kajian empiris dari (Fisher, 2012) yang menemukan keanehan pola menabung pada masyarakat dengan tingkat income yang berbeda. Disimpulkan pada penelitian tersebut bahwa umumnya masyarakat dengan income yang rendah cenderung menabung lebih pendek daripada masyarakat dengan income tinggi. Terdapat perbedaan time preference tabungan individu sesuai dengan tingkat income. Gagasan ini sendiri sebenarnya juga sudah dibahas oleh (Smith, 2013) dalam "Theory of Moral Sentiment". Teori ini menyatakan bahwa manusia lebih menyukai "kenikmatan" saat ini dibandingkan nanti. Bahasan ini telah dibuat sangat lama sekali akan tetapi jarang diangkat dalam penelitian karena sulitnya dalam mengukur perilaku dan pola pengambilan keputusan manusia. Akan tetapi ketika dikenalkannya prospect theory oleh (Kahneman, Thinking, Fast and Slow, 2013) pembahasan mengenai perilaku dan pengambilan keputusan dalam ilmu keuangan menjadi topik yang terkini. 
Untuk mengkonfirmasi fenomena anomali pasar serta menjadi jembatan pada ilmu behavior economics maka penelitian ini akan:

1. Mendeteksi anomali, dengan mengukur terjadinya abnormal return pada saham consumer goods sub sektor 1 , food \& beverage. Umumnya secara heuristic kita sering mendengar bahwa saham sektor ini menjadi primadono sewaktu menjelang lebaran. Ada asosiasi yang terbentuk pada "investor awam" bahwa menjelang lebaran, orang-orang meningkatkan konsumsi (terutama makanan dan minuman) untuk menyambut hari raya. Akibatnya akan meningkatkan "harga" saham sektor tersebut. Pertanyaan dari fenomena tersebut adalah apakah memang benar peningkatan konsumsi itu terjadi? Kedua, jika memang terjadi peningkatan konsumsi, apakah benar peningkatan volume konsumsi masyarakat langsung berpengaruh pada harga saham sektor food \& beverage?

2. Melakukan mini survey sederhana pada masyarakat (khususnya rumah tangga) untuk mendeteksi peningkatan konsumsi. Setelah itu diajukan beberapa pertanyaan mengenai pendapat masyarakat dengan saham sektor food \& beverage tersebut.

3. Dari mini survey juga diberikan 3 pertanyaan mengenai studi perilaku manusia, terutama terkait penggunaan uang dan utility bagi masyarakat umum. Pertanyaan ini berusaha untuk menerangkan sebuah teori mengenai loss aversion terkait rasa kecewa yang tinggi terhadap situasi kehilangan (terutama uang).

\subsection{Landasan Masalah}

Masalah perilaku irasional dari investor (manusia) umumnya membawa masalah kepada akurasi dari model keuangan yang dibangun atas dasar rasionalitas manusia. Contoh fenomena yang akan dibahas pada penelitian ini adalah kecenderungan orang untuk langsung berkesimpulan saham sektor consumer goods (dalam bahasan ini sub sektor food \& beverage) akan naik (terjadi anomali harga saham) ketika menjelang hari raya. Padahal belum tentu ada benang merah antara peningkatan konsumsi konsumen dengan belanja investor (Lebaran Effect). Selain itu riset ini juga memperkaya analisis dengan menambahkan deteksi pada dua anomali yang lain yakni Monday Effect dan January Effect. Secara rinci maka rumusan masalah anomali pasar yang hendak dibahas dalam penelitian ini:

1. Apakah terjadi anomali pasar yang terjadi menjelang hari lebaran (Lebaran Effect)?

2. Apakah terjadi anomali pasar yang terjadi pada bulan Januari (January Effect)?

3. Apakah terjadi anomali pasar yang terjadi pada awal pekan (Monday Effect)?

Selain itu, untuk menambah kebaruan dari penelitian ini sekaligus "jembatan" pada kajian perilaku ekonomi, maka ditambahkan survey untuk mengkonfirmasi peningkatan konsumsi rumah tangga pada menjelang lebaran dan juga pendapat masyarakat umum pada saham sub sektor food \& beverage. Dan juga apakah benar sebuah teori mengenai loss aversion terjadi pada responden.

\section{TINJAUAN LITERATUR DAN HIPOTESIS}

\subsection{Perkembangan Ilmu Keuangan, Investasi, \& Loss Aversion}

Dalam ilmu keuangan maka kajian mengenai anomali pasar merupakan fenomena yang menarik. Sebelum masuk ke anomali pasar maka terlebih dahulu ada sebuah teori yang bernama efficient market hypothesis (EMH). (Fama, 1970) pertama kali 
memperdebatkan anomali yang terjadi pada pasar modal dan memperkenalkan teori mengenai pasar efisien. Teori ini banyak dipelajari oleh mahasiswa terutama yang mengambil kelas manajemen keuangan. Dalam kajian ini pasar terbagi atas 3 bentuk yakni weak form, semi-strong form dan strong form. Perbedaan dari ketiga pasar tersebut adalah penyerapan informasi saja. Jika memang pasar sudah efisien (strong form) maka seharusnya aliran informasi begitu cepat terserap dan tidak memungkinkan terjadinya abnormal return. Tentunya kajian ini memperdebatkan model CAPM yang sangat populer mengenai teori pembentukan portofolio optimal oleh (Markowitz, 1952). Model CAPM sendiri dikembangkan oleh beberapa peneliti berdasarkan penelitian (Markowitz, 1952) tersebut. Pembentukan portfolio "optimal" ini diperkenalkan sebagai landasan teori mengenai risiko dan tingkat pengembalian investasi. Pembentukan portofolio investasi tersebut dibentuk dengan asas meminimalkan risiko sehingga terjadi diversifikasi investasi bagi para investor. Dalam buku investasi sendiri tingkat pengembalian (return) sendiri dihitung sebagai:

\section{return $=$ dividend + capital gain $($ Jones, 2009)}

Harga saham yang berubah-ubah dari waktu ke waktu mengakibatkan apresiasi dan depresiasi dari nilai investasi. Akan tetapi apakah memang perubahan harga tersebut memang didorong oleh nilai intrinsik perusahaan? Teori keuangan dan analisis fundamental selalu menekankan pada nilai intrinsik perusahaan. Nilai intrinsik ini tercermin dari kemampuan perusahaan untuk menghasilkan profit dan mampu bertahan dalam jangka panjang. Artinya perusahaan dengan nilai intrinsik yang tinggi memiliki nilai yang sangat tinggi di masa depan dan tidak akan tutup atau bangkrut. Mulai dari sini praktisi keuangan terpecah dan muncul bidang penelitian mengenai behavioral economics. Behavioral economics itu sendiri memiliki cakupan yang sangat luas. Mulai implementasi pada bidang pemasaran hingga behavior finance. Salah satu kajian rangkuman dari hasil behavioral economics itu sendiri dapat terlihat pada (Ariely, Behavioural Economics Save My Dog, 2015). Loss aversion adalah salah satu teori yang berusaha menjelaskan mengapa manusia umumnya merasa lebih kesal jika kehilangan sesuatu. Dalam teori ini menjelaskan "pain of losing something is twice as much as pleasure of gaining”. Dalam kajian psikologi (Kahneman, Thinking, Fast and Slow, 2013) kajian ini berusaha menjelaskan sebuah utility curve yang berbentuk S serta sangat subjektif tergantung dari manusia yang mengalaminya. Sebagian besar kajian behavior economics berbasis pada riset eksperimental. Penelitian ini diharapkan dapat berperan sebagai jembatan antara ilmu keuangan klasik dengan ilmu keuangan baru yang berbasis pada studi perilaku. Sebelum masuk ke kajian perilaku yang berbasis pada eksperimen maka pembahasan anomali masih cukup menarik untuk dikaji secara empiris. Jika memang ditemukan anomali maka teori pasar modal klasik sudah tidak cukup baik dalam menjelaskan perubahan harga saham dan nilai investasi. Anomali yang akan diangkat dalam penelitian ini adalah Lebaran Effect, January Effect dan Monday Effect.

\subsection{Anomali Pasar Modal dan Fenomenanya}

Secara umum anomali pasar modal dapat dikatakan sebagai kondisi di mana harga saham berubah secara drastic (bisa naik atau turun) pada suatu waktu. Umumnya hal itu terjadi karena adanya reaksi pasar yang tidak dapat diprediksi sebagai contoh ketika terjadi pemberitaan pemakzulan Donald Trump bursa Amerika Serikat bergerak turun. Hanya saja ada beberapa fenomena menarik yang terjadi dikarenakan adanya heuristic 
bias yang belum tentu dikonfirmasi oleh pelakunya. Lebaran Effect merupakan fenomena di mana harga saham cenderung lebih tinggi menjelang hari raya, sedangkan setelahnya akan kembali normal. Lebaran Effect itu sendiri merupakan salah satu fenomena yang tergolong holiday effect pada penelitian anomali. Sedangkan January Effect merupakan fenomena terdapat peningkatan harga saham pada bulan januari sedangkan Monday Effect menyatakan harga saham cenderung lebih rendah pada hari senin. Hal ini mengakibatkan munculnya berbagai mitos bahwa setiap hari jumat terjadi profit taking oleh investor, setiap bulan januari banyak investor yang melakukan pembelian dan menjelang hari raya (lebaran) maka transaksi dan volume saham cenderung tinggi. Yang menjadi fokus utama penelitian ini adalah Lebaran Effect. (Marini, 2016) meneliti mengenai efek hari Idul Fitri terhadap return saham khusus untuk sub sektor food \& beverage. Dalam analisisnya digunakan perhitungan abnormal return (rata-rata) dan non-parametric test - Wilcoxon Signed Test untuk menguji apakah terdapat perbedaan transaksi saham pada hari menjelang lebaran. Penelitian ini menemukan tidak terbukti adanya lebaran effect pada data saham 2011 hingga 2015 pada sampel penelitian. Pada penelitian lain (Rukmana, 2013) hasil yang diperoleh sedikit berbeda. Dengan menggunakan Mann Whitney Test pada sampel penelitian ditemukan hanya pada perusahaan dengan kapitalisasi besar saja terbukti bahwa terjadi lebaran effect. Sedangkan pada perusahaan dengan kapitalisasi kecil tidak ditemukan hal tersebut. (Febrianto, 2015) dalam penelitiannya pada saham JII (Jakarta Islamic Index) menemukan terdapat reaksi pasar sebelum hari lebaran. Dalam periode 15 hari pengamatan sebelum lebaran dan 15 hari sesudah lebaran berdasarkan observasi abnormal return dan hasil uji t, ditemukan terdapat perbedaan sebelum dan sesudah lebaran. Kajian event study tersebut juga dikonfirmasi oleh perbedaan trading volume activity. (Utomo \& Herlambang, 2015) melakukan pengamatan pada abnormal return dan abnormal trading volume activity. Sampel penelitian adalah 31 perusahaan paad indeks ISSI yang diamati 30 hari sebelum lebaran dan 10 hari setelah lebaran. Hasil penelitian kembali menyanggah bahwa tidak ditemukan perbedaan abnormal return pada hari sebelum dan sesudah lebaran, akan tetapi ditemukan terdapat perbedaan pada trading volume activity. (Aryanto, 2006) menggunakan uji t pada 4 hari sebelum lebaran pada abnormal return pada 42 perusahaan dan menemukan terdapat perbedaan signifikan dari periode observasi. Dari kelima penelitian tersebut, ditemukan bahwa 3 penelitian mengkonfirmasi terjadinya anomali sedangkan 2 tidak. Penelitian tersebut juga menggunakan abnormal return sebagai ukuran untuk mendeteksi anomali dengan berbagai pengujian non parametris. Dalam banyak literasi keuangan seperti (Jones, 2009) dan (Hartono, 2017) abnormal return merupakan selisih antara actual return dikurangi dengan expected return. Jika dirumuskan maka:

$$
A R_{i, t}=R_{i, t}-E(R)_{i, t}
$$

Terdapat banyak perdebatan perhitungan expected return. Biasanya dalam penelitian expected return akan menggunakan kaidah CAPM dengan memperhitungan return market (dalam hal ini IHSG). Akan tetapi pada penelitian ini, perhitungan expected return menggunakan nilai rata-rata return harian dari masing-masing saham pada setiap bulannya. Penelitian ini menggunakan pendekatan tersebut dengan harapan mengurangi kesalahan dalam penggunaan IHSG sebagai indikator expected return. IHSG sendiri merupakan indeks pasar modal Indonesia, yang jika digunakan pada semua saham dikhawatirkan kurang tepat dan membuat tingkat kesalahan menjadi tinggi. 


\subsection{Loss Aversion, Prospect Theory dan Anomali Pasar}

Loss aversion merupakan sebuah gagasan bahwa umumnya seorang individu cenderung akan merasakan losing lebih kuat efeknya dari pada gain sesuatu dalam jumlah yang sama. Sebagai contoh, teori ini menggagas jika A mendapatkan 100,000 dan pada hari yang sama juga dia harus membayar 100,000 tersebut, maka utility atau tingkat kebahagiaan dari A harusnya kurang dari kebahagiaan mula-mula. Jadi dengan matematika, katakan A memiliki (u) ketika belum memiliki uang. Ketika dia mendapatkan uang kebahagiaannya menjadi (u1), dan ketika kehilangan uang menjadi (u3). Dalam pertidaksamaan, kondisi akhir A adalah u3 $<\mathrm{u} 1<\mathrm{u} 2$. Pembahasan teori ini dirangkum dalam (Kahneman, Thinking, Fast and Slow, 2013) yang merupakah hasil riset dari (Tversky \& Kahneman, 1991).

Menelusuri lebih jauh, kajian ini pertama kali diperkanalkan dalam (Kahneman \& Tversky, Prospect Theory: An Analysis of Decision Under Risk, 1979). Pada mulanya mereka menyebutnya sebagai prospect theory karena pada penelitian ini mereka memberikan berbagai pilihan prospek untuk dipilih oleh objek penelitian mereka lalu mengembangkan sebuah model dan teori untuk menyangkal bahwa utilitiy yang dirasakan manusia tidak linear, terutama terkait dengan kondisi losing. Teori ini menjawab kenapa manusia cenderung lebih lama untuk melupakan sesuatu yang sifatnya merugikan ataupun menyakiti mereka.

Dalam perkembangannya memang telah menjadi sebuah perdebatan bahwa anomali pasar adalah fenomena yang gagal dijelaskan oleh teori pasar efisien (EMH). Akan tetapi dugaaan penyebabnya mungkin terletak pada proses sebelum transaksi jual dan beli saham itu terjadi, yakni pengambilan keputusan investor. Prospect Theory, secara spesifik loss aversion menawarkan sebuah penjelasan terjadinya panik atau market overaction dikarenakan investor (yang dalam konteks ini adalah manusia) terlalu panik atau gembira untuk membuat keputusan yang efisien sehingga bertransaksi tergantung pada berita dan rumor.

\subsection{Hipothesis Penelitian}

Hipothesis yang akan diuji pada penelitian ini adalah:

1. Hari Lebaran (Idul Fitri) menyebabkan terjadinya abnormal return

2. Pada bulan januari ditemukan terjadinya abnormal return

3. Pada hari senin ditemukan terjadinya abnormal return

Setelah menguji hypothesis penelitian, maka mini survey akan dilakukan sebagai pembanding atas temuan anomali tersebut. Mini survey hanya bersifat konfirmatori dan mendeskripsikan apakah masyarakat secara umum memang meningkatkan konsumsi mereka (terutama terhadap barang yang dijual oleh perusahaan food \& beverage) menjelang lebaran. Selain itu mini survey juga membidik teori loss aversion serta mengkonfirmasi kebenaran teori tersebut.

\section{METODOLOGI PENELITIAN}

Penelitian ini menerapkan metode kuantitatif dalam menganalisis data. Data penelitian diambil dari yahoo finance, untuk data harga saham sektor consumer goods sub sektor food \& beverage. Data diambil dalam rentang februari 2015 hingga februari 2020. Dalam melakukan sampling metode yang digunakan adalah purposive sampling sehingga diperoleh jumlah perusahaan yang memenuhi kriteria penelitian adalah 16 perusahaan. 
Untuk menganalisis efek anomali (Lebaran Effect, January Effect, dan Monday Effect) maka digunakan model regresi dummy seperti berikut ini:

Lebaran Effect: Abnormal Return $n_{\mathrm{i}, \mathrm{t}}=\mathrm{a}+\mathrm{bD}_{\mathrm{LEB}}+\mathrm{e}_{\mathrm{i}}$

January Effect: Abnormal Return $n_{i, t}=\mathrm{a}+\mathrm{b}_{1} \mathrm{D}_{1}+\mathrm{b}_{2} \mathrm{D}_{2}+\mathrm{b}_{3} \mathrm{D}_{3}+\mathrm{b}_{4} \mathrm{D}_{4}+\mathrm{b}_{5} \mathrm{D}_{5}+\mathrm{b}_{6} \mathrm{D}_{6}+$ $\mathrm{b}_{7} \mathrm{D}_{7}+\mathrm{b}_{8} \mathrm{D}_{8}+\mathrm{b}_{9} \mathrm{D}_{9}+\mathrm{b}_{10} \mathrm{D}_{10}+\mathrm{b}_{11} \mathrm{D}_{11}+\mathrm{e}_{\mathrm{i}}$

Monday Effect: Abnormal Return $n_{i, t}=\mathrm{a}+\mathrm{b}_{1} \mathrm{D}_{\mathrm{a}}+\mathrm{b}_{2} \mathrm{D}_{\mathrm{b}}+\mathrm{b}_{3} \mathrm{D}_{\mathrm{c}}+\mathrm{b}_{4} \mathrm{D}_{\mathrm{d}}+\mathrm{e}_{\mathrm{i}}$

Keterangan:

Abnormal Return $_{\mathrm{i}, \mathrm{t}}=$ variabel terikat, nilai abnormal return dari perusahaan i pada tahun waktu $\mathrm{t}$

a $\quad=$ Konstanta model penelitian

$\mathrm{b}_{1}-\mathrm{b}_{\mathrm{n}} \quad=$ Koefisien / Slope model penelitian

D $\quad$ LEB $\quad$ Variabel Dummy untuk Lebaran Effect

$\mathrm{D}_{1-12} \quad=$ Variabel Dummy untuk January Effect

$\mathrm{D}_{\mathrm{a}-\mathrm{d}} \quad=$ Variabel Dummy untuk Monday Effect

$\mathrm{E}_{\mathrm{i}} \quad=$ Error Term

Penelitian ini terdiri atas 2 bagian. Pada bagian pertama, untuk menganalisis model penelitian dan hypothesis maka digunakan regresi linear (OLS). Dari analisis OLS maka uji $\mathrm{t}$ akan digunakan sebagai acuan pengambilan kesimpulan dari hypothesis penelitian (dengan tingkat kesalahan sebesar 5\% - two tail test). Dalam analisis model pertama (Lebaran Effect), maka rentang hari observasi yang digunakan adalah 10 hari sebelum dan 10 hari sesudah lebaran. Selain itu nilai adjusted $R^{2}$ juga akan diamati untuk mengkonfirmasi kemampuan penjelas variabel bebas terhadap variabel terikat dengan menggunakan model regresi dummy termasuk dalam kategori fit. Pada variabel dummy jumlahnya disesuaikan dengan control variable. Dalam konteks ini, untuk dummy bulan terdapat 12 bulan dalam satu tahun, penelitian ini menggunakan December sebagai dummy control sehingga jumlah D untuk model 2 hanya sebatas 11 saja. Model penelitian tersebut berusaha untuk mendeteksi abnormal return pada bulan-bulan selain desember apakah berbeda. Ekspekstasi hasil penelitian hendaknya pada D1 dideteksi perbedaan abnormal return. Untuk model 3 prinsip yang sama juga berlaku, hari jumat sebagai control variable dan diharapkan hasil dummy a signifikan secara statistic.

Pada bagian kedua, maka hasil deskriptif dari "mini survey" akan dijadikan sebagai pembanding dan konfirmasi atas mitos yang selama ini berkembang mengenai setiap kali menjelang lebaran, harga saham sektor food \& beverage cenderung naik. Dari mini survey diharapkan tergambarkan perilaku konsumsi dari sampel survey penelitian. Mini survey terdiri atas 3 bagian yakni:

1. Deskriptif responden

2. Pengetahuan akan 16 perusahaan sample penelitian dan pola konsumsi

3. Studi perilaku dengan beberapa pertanyaan terkait loss aversion

Berikut ini adalah pertanyaan untuk mendeteksi loss aversion 
Tabel 3.1 Pertanyaan Deteksi Loss Aversion

\begin{tabular}{|c|c|c|c|}
\hline No & Pertanyaan & Pilihan & Teori \\
\hline 1 & $\begin{array}{l}\text { Suatu hari, anda } \\
\text { belanja pada sebuah } \\
\text { Departement Store } \\
\text { dengan nilai } \\
\text { transaksi hingga } 2 \\
\text { Juta Rupiah. Ketika } \\
\text { hendak membayar } \\
\text { anda diberikan } \\
\text { pilihan berikut ini: } \\
\text { Manakah pilihan } \\
\text { yang akan anda } \\
\text { ambil? }\end{array}$ & $\begin{array}{lr}\begin{array}{l}\text { Melakukan } \\
\text { dengan } 90 \%\end{array} & \text { permainan } \\
\text { mendapatkan } & \text { cashback } \\
300,000 & \end{array}$ & $\begin{array}{l}\text { Umumnya pada pilihan } \\
\text { ini responden akan } \\
\text { masih akan terbagi } \\
\text { 50:50 tergantung dari } \\
\text { preferensi risiko. }\end{array}$ \\
\hline 2 & $\begin{array}{l}\text { Pada hari yang sama, } \\
\text { ternyata anda } \\
\text { melanggar rambu- } \\
\text { rambu lalu lintas, } \\
\text { pada saat polisi } \\
\text { hendak menilang } \\
\text { anda, maka anda bisa } \\
\text { melakukan hal } \\
\text { berikut ini. Pilihan } \\
\text { mana yang anda } \\
\text { ambil? }\end{array}$ & $\begin{array}{l}\text { Membayar denda sebesar } \\
200,000 \\
\text { Melakukan negosiasi, jika } \\
\text { gagal (90\% peluangnya) } \\
\text { maka anda kehilangan } \\
300,000\end{array}$ & $\begin{array}{l}\text { Berdasarkan teori, } \\
\text { responden akan memilih } \\
\text { melakukan gambling } \\
\text { dan memilih pilihan } \\
\text { kedua sebagai wujud } \\
\text { reaksi dari kondisi sure } \\
\text { loss }\end{array}$ \\
\hline 3 & $\begin{array}{l}\text { Ketika anda } \\
\text { mendapatkan } \\
\text { cashback } 200.000 \\
\text { dan pada hari yang } \\
\text { sama anda harus } \\
\text { membayar tilang } \\
\text { 200.000, berapakah } \\
\text { tingkat kebahagiaan } \\
\text { anda hari ini? }\end{array}$ & $\begin{array}{l}1: \text { Sangat Kesal } \\
5: \text { Sangat Bahagia }\end{array}$ & $\begin{array}{l}\text { Berdasarkan } r \text { teori } \\
\text { harusnya responden } \\
\text { merasa tidak bahagia } \\
\text { dan skor harusnya } \\
\text { berada di } 1 \text { hingga } 2 .\end{array}$ \\
\hline
\end{tabular}

Untuk pertanyaan 1 dan 2 itu merupakan pertanyaan terkait prospek. Responden diberikan opsi untuk memilih salah satu dari 2 prospek yang ditawarkan. Pendekatan ini dilakukan sesuai dengan penelitian pertama mengenai prospect theory oleh (Kahneman \& Tversky, Prospect Theory: An Analysis of Decision Under Risk, 1979). Sedangkan untuk opsi ke-3 digunakan skala likert dari 1 hingga 5. Tujuannya untuk mengukur tingkat utility responden sesuai dengan penilaian pribadi mereka masing-masing.

Penggabungan data primer dari mini survey dilakukan untuk sebagai komparasi rumor yang sering terjadi. Umumnya terbentuk opini saham consumer goods merupakan saham primadona saat menjelang lebaran tanpa ada penjelasan lebih lanjut. Dalam pelaksanaan mini survey pertanyaan dirancang untuk mengetahui pengetahuan responden terhadap produk dari perusahaan yang diobservasi fenomena anomalinya. Sebagai contoh, ada perusahaan Ades yang memproduksi air minum kemasan Ades. Selain itu beberapa PT yang tidak umum namanya tapi memproduksi produk yang mungkin 
konsumen tahu, yakni PT Budi Starch yang memproduksi tepung beras Rose Brand. Diakhir mini survey diselipkan pertanyaan terkait loss aversion di atas sesuai dengan tujuan penelitian ini adalah bridging anomali pasar pada behavior economics. Jumlah sampel yang ditargetkan pada penelitian ini adalah 30 responden. Jumlah ini disesuaikan dengan (Lind, Marchal, \& Wathen, 2008) yang menyatakan untuk mengaplikasikan central limit theorem jumlah sampel 30 dirasa cukup sebagai jumlah minimum.

\section{HASIL DAN PEMBAHASAN}

\subsection{Statistik Deskriptif}

Hasil pemaparan data return saham sub sektor food \& beverage dapat terlihat pada tabel 4.1. Sampel yang memenuhi kriteria penelitian untuk mendeteksi abnormal return ditemukan ada 16 perusahaan. Perusahaan-perusahaan tersebut menjual produk minuman hingga roti. Berdasarkan data harian, maka hasil yang diperoleh setelah dirata-rata per tahun, maka tingkat pengembalian dari saham-saham ini berada pada rentang $-0.52 \%$ hingga $0.72 \%$. Nilai ini sangat kecil (tidak lebih dari $1 \%$ ), mengingat data dihasilkan berdasarkan nilai rata-rata data return harian dari saham-saham tersebut. Menariknya IIKP merupakan perusahaan dengan rata-rata return terkecil, yang terjadi pada tahun 2019 sekaligus perusahaan dengan rata-rata return tertinggi pada tahun 2015. PT Inti Agri Resources sendiri memang sudah mengalami rapor merah sejak awal tahun 2019. Hal ini diperburuk oleh situasi dikuranginya kepemilikan atas saham ini (IIKP) oleh PT ASABRI (Persero) yang merupakan BUMN pengelola dana asuransi dan jaminan sosial bagi TNI, Polri, dan PNS Kementerian Pertahanan. Tentunya kasus ASABRI ini juga masih sangat hangat terutama ketika Menteri BUMN, Erick Tohir mulai memantau tata kelola dan penggunaan dana BUMN dan terkuaknya kasus Jiwasraya.

Tabel 4.1 Hasil Deskriptif Rata-Rata Return Saham Sub Sektor Food \& Beverage

\begin{tabular}{llllll}
\hline PT & $\mathbf{2 0 1 5}$ & $\mathbf{2 0 1 6}$ & $\mathbf{2 0 1 7}$ & $\mathbf{2 0 1 8}$ & $\mathbf{2 0 1 9}$ \\
\hline ADES & $-0.11 \%$ & $0.01 \%$ & $-0.03 \%$ & $0.03 \%$ & $0.07 \%$ \\
ALTO & $-0.01 \%$ & $0.01 \%$ & $0.15 \%$ & $0.05 \%$ & $0.01 \%$ \\
BTEK & $0.24 \%$ & $0.04 \%$ & $0.11 \%$ & $0.11 \%$ & $-0.31 \%$ \\
BUDI & $-0.19 \%$ & $0.18 \%$ & $0.05 \%$ & $0.09 \%$ & $0.05 \%$ \\
CEKA & $0.05 \%$ & $0.37 \%$ & $0.06 \%$ & $0.08 \%$ & $0.16 \%$ \\
DLTA & $-0.14 \%$ & $0.02 \%$ & $-0.02 \%$ & $0.09 \%$ & $0.12 \%$ \\
ICBP & $0.01 \%$ & $0.13 \%$ & $0.03 \%$ & $0.08 \%$ & $0.04 \%$ \\
IIKP & $0.72 \%$ & $-0.10 \%$ & $0.19 \%$ & $-0.02 \%$ & $-0.52 \%$ \\
INDF & $-0.12 \%$ & $0.21 \%$ & $0.00 \%$ & $0.03 \%$ & $0.05 \%$ \\
MGNA & $-0.19 \%$ & $0.25 \%$ & $0.28 \%$ & $-0.07 \%$ & $0.00 \%$ \\
MLBI & $-0.13 \%$ & $0.19 \%$ & $0.08 \%$ & $0.08 \%$ & $0.00 \%$ \\
PSDN & $0.04 \%$ & $0.21 \%$ & $0.41 \%$ & $0.06 \%$ & $0.11 \%$ \\
ROTI & $0.00 \%$ & $0.12 \%$ & $-0.07 \%$ & $-0.01 \%$ & $0.04 \%$ \\
SKBM & $0.05 \%$ & $-0.03 \%$ & $0.16 \%$ & $0.13 \%$ & $0.04 \%$ \\
TBLA & $-0.09 \%$ & $0.31 \%$ & $0.11 \%$ & $-0.08 \%$ & $0.09 \%$ \\
ULTJ & $0.01 \%$ & $0.08 \%$ & $0.07 \%$ & $0.05 \%$ & $0.10 \%$ \\
\hline
\end{tabular}


Tabel 4.2 Hasil Deskriptif Rata-Rata Abnormal Return per Bulan Saham Sub Sektor Food \& Beverage

\begin{tabular}{llllll}
\hline Bulan & $\mathbf{2 0 1 5}$ & $\mathbf{2 0 1 6}$ & $\mathbf{2 0 1 7}$ & $\mathbf{2 0 1 8}$ & $\mathbf{2 0 1 9}$ \\
\hline 1 & $0.00 \%$ & $0.04 \%$ & $0.34 \%$ & $-0.14 \%$ & $-0.71 \%{ }^{* *}$ \\
2 & $0.02 \%$ & $-0.12 \%$ & $-0.44 \% * *$ & $0.06 \%$ & $0.34 \% *$ \\
3 & $0.16 \%$ & $0.13 \%$ & $-0.31 \%$ & $0.22 \%$ & $-0.55 \%$ \\
4 & $-0.29 \%$ & $0.28 \%$ & $-0.12 \%$ & $-0.01 \%$ & $-0.07 \%$ \\
5 & $0.06 \%$ & $0.45 \%$ & $0.62 \% *$ & $-0.08 \%$ & $0.23 \%$ \\
6 & $-0.22 \%$ & $-1.03 \% * *$ & $-0.07 \%$ & $-0.21 \% * *$ & $-0.13 \%$ \\
7 & $-0.19 \%$ & $0.01 \%$ & $0.35 \%$ & $-0.04 \%$ & $-0.30 \%$ \\
8 & $0.49 \%$ & $0.29 \%$ & $0.04 \%$ & $0.14 \%$ & $0.24 \%$ \\
9 & $0.40 \%$ & $0.40 \%$ & $0.14 \%$ & $-0.01 \%$ & $0.19 \%$ \\
10 & $0.36 \%$ & $0.43 \%$ & $-0.04 \%$ & $-0.01 \%$ & $-0.13 \%$ \\
11 & $-0.54 \% * *$ & $-0.05 \%$ & $0.58 \%$ & $-0.09 \%$ & $0.22 \%$ \\
12 & $1.03 \% *$ & $0.64 \% *$ & $0.39 \%$ & $0.41 \% *$ & $-0.08 \%$ \\
\hline
\end{tabular}

* rata-rata abnormal return tertinggi

** rata-rata abnormal return terendah

Berdasarkan hasil abnormal return maka ditemukan bahwa pada bulan-bulan Desember (tahun 2015, 2016, dan 2018) ditemukan cenderung lebih tinggi dibandingkan bulan-bulan lainnya. Sedangkan pada tahun 2017 dan 2019, abnormal return tertinggi terjadi pada bulan Mei dan Februari. Untuk pola abnormal return terendah, terjadi sangat variatif dari tahun 2015 hingga tahun 2019. Dari hasil paparan deskriptif ditemukan bahwa nilai terendah terjadi pada Juni 2016.

Berdasarkan prinsip ekonomi, maka harga terbentuk sesuai dengan hukum permintaan dan penawaran. Begitu juga dengan pasar modal, ketika banyak pembeli (bidder) tapi sedikit penjual (seller) maka para penjual cenderung menghargai barang yang mereka miliki lebih mahal dan hasilnya adalah harga bergerak naik. Akan tetapi kompleksitas pasar modal tidak dapat diterangkan dengan hubungan sederhana tersebut. Pelaku dalam transaksi efek tidak hanya individu tetapi juga pembeli-pembeli besar seperti manajer investasi dan institusi keuangan lainnya seperti asuransi dan dana pensiun. Oleh karena banyak pihak yang terlibat maka hasilnya adalah kemungkinan terjadinya anomali sangat tinggi. Apalagi terjadi panik ataupun euphoria yang berlebihan, maka unusual market activity dapat terjadi.

\section{Deteksi Anomali}

Untuk mendeteksi anomali, maka terdapat 3 model penelitian yang digunakan pada penelitian ini:

\section{Lebaran Effect:}

Abnormal Return ${ }_{i, t}=a+b_{\text {LEB }}+e_{i}$

January Effect:

Abnormal Return $n_{i, t}=a+b_{1} D_{1}+b_{2} D_{2}+b_{3} D_{3}+b_{4} D_{4}+b_{5} D_{5}+b_{6} D_{6}+b_{7} D_{7}+b_{8} D_{8}+b_{9} D_{9}$

Monday Effect:

$$
+b_{10} D_{10}+b_{11} D_{11}+e_{i}
$$

Abnormal Return $i, t=a+b_{1} D_{a}+b_{2} D_{b}+b_{3} D_{c}+b_{4} D_{d}+e_{i}$ 
Ketiga model menggunakan variabel dummy untuk membantu mendeteksi abnormal return pada dugaan penelitian sebelumnya.

Hasil dari regresi ketiga model tersebut adalah:

Dalam ketiga model regresi tersebut, variabel dummy digunakan untuk mengindentifikasi sebuah event terkait dengan anomali tersebut. Jumlah data yang digunakan untuk analisis adalah sebanyak 20,048 data (terdiri atas data abnormal return harian dari 16 sampel perusahaan). Oleh karena itu tidak dilakukan lagi uji normalitas untuk residual model regresi tersebut dikarenakan jumlah sampel yang sudah sangat besar (central limit theorm).

Tabel 4.3 Hasil Uji Model Regresi Penelitian

\begin{tabular}{llll}
\hline Indikator & Model_1 & Model_2 & Model_3 \\
\hline R & 0.011 & 0.06 & 0.017 \\
R Square & 0 & 0.004 & 0 \\
Adjusted R Square & 0 & 0.003 & 0 \\
F & 2.316 & 6.552 & 1.371 \\
sig (F) & 0.128 & $0 *$ & 0.241 \\
DW & 2.139 & 2.145 & 2.138 \\
\hline \multicolumn{4}{c}{}
\end{tabular}

Pada tabel 4.3 hasil persamaan regresi dengan model variabel dummy tersebut ditemukan goodness of fit dari model sangat kecil. Variabilitas ketiga model yang dapat dijelaskan oleh variable dummy hanya sekitar 0 hingga $0.4 \%$ saja. Temuan ini menggambarkan dalam menganalisis data ini, maka diperlukan pendekatan lain seperti non-parametric test untuk mengkonfirmasi kembali temuan ini.

Tabel 4.4 Hasil Pengujian t-test dan Koefisien Regresi

\begin{tabular}{llll} 
Keterangan & Coef & t-test & sig(t) \\
\hline Model_1 & & & \\
(Constant) & 0.001 & 2.846 & $0.004^{*}$ \\
Hari_Raya & -0.001 & -1.522 & 0.128 \\
Model_2 & & & \\
(Constant) & 0.005 & 5.749 & $0 *$ \\
Jan & -0.006 & -4.713 & $0 *$ \\
Feb & -0.005 & -4.271 & $0 *$ \\
Mar & -0.006 & -4.719 & $0 *$ \\
Apr & -0.005 & -4.521 & $0 *$ \\
Mei & -0.002 & -2.022 & $0.043^{*}$ \\
Jun & -0.008 & -6.976 & $0 *$ \\
Jul & -0.005 & -4.357 & $0 *$ \\
Aug & -0.003 & -2.154 & $0.031^{*}$ \\
Sep & -0.003 & -2.194 & $0.028^{*}$ \\
Oct & -0.004 & -3.188 & $0.001^{*}$ \\
Nov & -0.005 & -3.921 & $0 *$
\end{tabular}




\begin{tabular}{llll}
\hline Keterangan & Coef & t-test & sig(t) \\
\hline Model_3 & & & \\
(Constant) & 0.001 & 1.937 & 0.053 \\
Mon & -0.002 & -2.032 & $0.042 *$ \\
Tue & 0 & -0.28 & 0.779 \\
Wed & 0 & -0.448 & 0.654 \\
Thur & 0 & -0.135 & 0.892 \\
\hline \multicolumn{5}{r}{} & * significant pada alpha 5\%
\end{tabular}

Temuan dari t-test yang diterapkan pada model mengkonfirmasi bahwa dengan pendekatan variabel dummy ditemukan anomali pasar modal. Pada model 1, terbukti nilai p-value yang kurang dari 0.05 mengkonfirmasi hypothesis penelitian pertama. Sedangkan pada model 2, ditemukan beberapa anomali pada setiap bulan. Artinya secara rata-rata sebenarnya performa return yang dihasilkan per hari selalu lebih tinggi dari rata-rata per bulannya (expected). Sedangkan pada model ketiga, terbukti hanya pada hari senin saja terjadi abnormal return berdasarkan hasil p-value yang kurang dari 5\%.

Implikasi dari temuan ini adalah memang permasalahan anomali pasar modal masih merupakan isu yang relevan hingga saat ini. Akan tetapi dalam menganalisis kenapa anomali itu terjadi maka dibutuhkan kajian yang lebih dalam. Penelitian ini terbatas sekali hanya pada persoalan mendeteksi anomali dan memang analisis ekonometrik masih sangat mampu dalam membaca data-data tersebut. Ketika nilai adjusted $\mathrm{R}^{2}$ dari ketiga model dilihat, maka hanya $0.4 \%$ saja anomali pasar modal bisa dijelaskan oleh data-data historis. Cabang ilmu psikologi memang menawarkan teori mengenai bagaimana manusia bisa membuat keputusan berdasarkan sistem berpikir (Kahneman, Thinking, Fast and Slow, 2013). Akan tetapi kajian psikologi dalam mengukur human utility sendiri mempunyai tantangan dalam membuat ukuran yang pasti untuk tingkat kebahagiaan (utility) dari manusia.

Untuk mendukung temuan data sekunder di atas, maka hasil mini survey dijadikan pembanding. Survey singkat ini berhasil mengumpulkan sampel sebanyak 45 responden. Responden sebagian besar (hampir 60\%) berasal dari kelompok umur 27 - 33 tahun. Ketika ditanya apakah responden meningkatkan konsumsi atas produk food \& beverage ditemukan 18 responden yang menyatakan setuju dengan kondisi tersebut. Selain itu intensitas responden ke supermarket menjelang lebaran juga ditemukan cukup tinggi. Ditemukan 18 responden setuju bahwa mereka meningkatkan intensitas mereka ke supermarket atau groceries stores. Temuan deskriptif ini mengkonfirmasi bahwa memang terdapat sebuah fenomena menjelang lebaran kebutuhan akan food \& beverage meningkat. Ada beberapa faktor yang menyebabkan ini terjadi. Pertama, dugaan peneliti ini disebabkan oleh culture effect dari masyarakat Indonesia yang masih menggarisbawahi budaya untuk "menjamu" tamu ketika hari raya. Kedua, kebetulan rumah tangga punya waktu luang, sehingga menyempatkan diri untuk berbelanja bersama di supermarket. Ketiga, karena hari libur, maka waktu untuk "stay at home" (bagi yang tidak keluar kota), sehingga mereka pasti membutuhkan ransum selama liburan. Dari ketiga kondisi tersebut, memang culture effect masih dirasa paling kuat sebagai penyebab tingginya intensitas belanja retail menjelang hari raya.

Hasil sederhana dari deskripsi mini survey juga mendeskripsikan hanya $31 \%$ dari responden saja yang pernah bertransaksi jual beli saham. Penelitian ini memang mengkonfirmasikan terjadi peningkatan konsumsi yang mungkin bisa berakibat ke seasonal effect pada pelaku usaha retail. Akan tetapi apakah ini profitable masih belum 
dapat dibuktikan. Memang benar terjadi peningkatan sales pada bulan tersebut, akan tetapi jika tidak diimbangi dengan efisiensi kegiatan operasional maka dampak tersebut juga masih dirasa kurang bagus untuk perusahaan sub sektor industri food \& beverage. Oleh karena itu, "kurang tepat" jika ada sebuah pernyataan peningkatan konsumsi hari raya juga mempengaruhi abnormal return dari perusahaan sub sektor ini. Tidak ditemukan benang merah juga antara fenomena ini bagaimana konsumsi masyarakat umum juga sejalan dengan volatilitas pasar modal. Padahal pelaku pasar modal belum tentu orang-orang masyarakat umum tersebut.

Hasil teori mengenai loss aversion membuktikan:

Tabel 4.5 Hasil Pertanyaan Loss Aversion

\begin{tabular}{|c|c|c|}
\hline Pertanyaan & Hasil & Implikasi \\
\hline 1 & $\begin{array}{l}\text { Mendapatkan cashback } 200,000 \\
\text { atas belanja anda } \\
(73 \%) \\
\text { Melakukan permainan dengan } \\
90 \% \text { peluang mendapatkan } \\
\text { cashback } 300,000 \\
(27 \%)\end{array}$ & $\begin{array}{l}\text { Umumnya tergantung } \\
\text { preferensi risiko dari seseorang. } \\
\text { Hasil ini menunjukan sebagian } \\
\text { besar responden adalah orang- } \\
\text { orang yang menghindari risiko }\end{array}$ \\
\hline 2 & $\begin{array}{l}\text { Membayar denda sebesar 200,000 } \\
(82 \%) \\
\text { Melakukan negosiasi, jika gagal } \\
(90 \% \text { peluangnya) maka anda } \\
\text { kehilangan 300,000 } \\
(18 \%)\end{array}$ & $\begin{array}{l}\text { Hasil ini berlawanan dengan } \\
\text { teori. Umumnya pada kondisi } \\
\text { sure loss maka orang cenderung } \\
\text { melakukan gambling. Namun } \\
\text { hasil ini mengkonfirmasi } \\
\text { kebanyak responden lebih } \\
\text { menyukai play save strategy }\end{array}$ \\
\hline 3 & Rata-Rata: 2.66 & $\begin{array}{l}\text { Kebanyakan responden } \\
\text { menjawab di angka } 3 \text {. Artinya } \\
\text { secara tanpa sadar responden } \\
\text { menghitung mendapatkan } \\
200,000 \text { dan kehilangan } \\
200,000 \text { dirasakan sebagai } \\
\text { kondisi yang impas. Hasil ini } \\
\text { berlawanan dengan teori yang } \\
\text { menyatakan harusnya } \\
\text { responden merasa lebih kesal. }\end{array}$ \\
\hline
\end{tabular}

Sebagai bentuk jembatan antara ilmu keuangan yang membahas anomali pasar dengan data sekunder, maka penelitian ini menemukan perbandingan yang cukup menarik. Hasil dari teori loss aversion tidak berhasil dikonfirmasi pada pertanyaan survey. Responden Indonesia lebih "sabar" dibandingkan hasil penelitian yang dilakukan peneliti di luar negeri (Kahneman, Thinking, Fast and Slow, 2013) (Thaler R. H., Misbehaving. The Making of Behavioral Economics, 2016). Pada penelitian sebelumnya, kebanyakan responden luar negeri dalam kondisi pasti rugi, mereka cenderung melakukan aksi atau memilih prospek yang beresiko. Ekspektasi dari pertanyaan saat ditilang polisi adalah mereka mencoba menegosiasi. Akan tetapi respon yang diperoleh dari riset ini, reponden cenderung taat dan mengikuti bayar tilang saja. Ada beberapa kemungkinan 
bagaimana ini bisa terjadi. Pertama bisa jadi memang perilaku kebanyakan responden adalah menghindari risiko (risk averse) sehingga sekalipun dalam kondisi terdesak mereka tetap menghindari risiko tersebut. Kedua adalah pertanyaan penelitian dirasa kurang cocok jika kasusnya adalah tilang, sebab menegosiasikan tilang merupakan tindakan melawan hukum sehingga bagi responden efek melawan hukum lebih berat dibandingkan mencoba menegosiasikannya. Sebagai langkah pertama dalam menjelaskan anomali pasar modal dengan teori loss aversion penelitian ini berakhir dengan pengembangan penelitian berbasis eksperimental untuk hasil yang lebih akurat.

\section{KESIMPULAN, KETERBATASAN DAN SARAN 5.1 Kesimpulan}

Kesimpulan yang berhasil diperoleh dari penelitian ini adalah:

1. Anomali pasar terbukti ditemukan berdasarkan pendekatan model regresi dengan dummy variables. Baik lebaran effect, January effect, dan Monday effect terbukti ada berdasarkan abnormal return yang diamati.

2. Setiap bulan terjadi abnormal return yang dapat disimpulkan umumnya return harian lebih tinggi dari performa rata-rata return bulanan. Oleh karena itu jika investor melakukan trading harian atas saham-saham yang diamati maka jauh lebih untung jika mereka melakukan transaksi harian. Akan tetapi hasil ini tidak memperhitungan trading fee dan pajak, yang bisa jadi jika diimplementasikan malah menjadi sebuah kerugian.

3. Mitos terkait bahwa menjelang lebaran konsumsi masyarakat meningkat terbukti dengan adanya hasil deskriptif mini survey. Hampir 50\% responden setuju mereka meningkatkan konsumsi atas makanan, minuman serta bertambah intens belanja di supermarket menjelang hari raya. Tentunya culture effect dari Indonesia sangat kental sehingga mengakibatkan masyarakat umumnya mempersiapkan kue-kue untuk menjamu tamu-tamu lebaran.

4. Hasil dari loss aversion tidak berhasil dikonfirmasi, akan tetapi diperlukan pendekatan lain untuk mengukur ini dari sekedar survey saja. Kesulitan dalam mengukur utility (tingkat kebahagiaan) memang menjadi sebuah penelitian di masa yang akan datang dari ilmu ekonomi, keuangan dan behavior economics.

\subsection{Keterbatasan}

Dalam pelaksanaan penelitian, sumber daya penelitian sangat terbatas. Umumnya dalam melakukan penelitian mengenai behavior terutama terkait loss aversion akan lebih akurat dengan menggunakan eksperimental dan permainan.

\subsection{Saran}

Dalam pengembangan penelitian, disarankan kajian ini dikembangkan dalam bentuk eksperimen untuk hasil yang lebih akurat. Kajian eksperimen dan observasi dapat melihat langsung interaksi objek penelitian dan memperoleh data yang lebih meaningful dibandingkan hanya menanyakan pada survey saja. 


\section{REFERENSI}

Aryanto, O. T. (2006). Pengaruh Lebaran Terhadap Pendapatan Abnormal Saham di Bursa Efek Jakarta. Universitas Airlangga. Surabaya: Repository Universitas Airlangga.

Ariely, D. (2015). Behavioural Economics Save My Dog. London: Oneworld Publications.

Ariely, D., \& Kreisler, J. (2017). Dollars and Sense. New York: HarperCollins Publishers.

Fama, E. F. (1970). Efficient Capital Markets: A Review of Theory and Empirical Work. Journal of Finance , 25 (2), 382-417.

Febrianto, A. R. (2015). Analisis Fenomena Anomali Pasar Lebaran Effect pada Saham di Jakarta Islamic Index (JII). Universitas Islam Sultan Agung. Semarang: Repository.

Fisher, I. (2012). The Theory of Interest as Determined by Impatience to Spend Income and Opportunity to Invest It. Martino.

Hartono, J. (2017). Teori Portofolio dan Analisis Investasi. Yogyakarta: BPFE UGM.

Jones, C. P. (2009). Investments. Principles \& Concepts. New York: Wiley.

Kahneman, D. (2013). Thinking, Fast and Slow. New York: Farrar, Straus and Giroux.

Kahneman, D., \& Tversky, A. (1979). Prospect Theory: An Analysis of Decision Under Risk. Econometrica , 47 (2), 263-291.

Lind, D. A., Marchal, W. G., \& Wathen, S. A. (2008). Statistical Techniques in Business \& Economics with Global Data Sets. New York: McGraw Hill.

Marini, E. (2016). Analisis Fenomena Hari Raya Idul Fitri Terhadap Return Saham dan Trading Volume Activity. Universitas Sebelas Maret, Fakultas Ekonomi \& Bisnis. Surakarta: Repository Universitas Sebelas Maret.

Markowitz, H. (1952). Portfolio Selection. Journal of Finance , 7 (1), 77-91.

Smith, A. (2013). The Theory of Moral Sentiment. CreateSpace Independent Publishing.

Rukmana, R. Z. (2013). Pengujian Idul Fitri Effect pada Pasar Modal Indonesia. Universitas Negeri Malang, Akuntansi. Malang: Repository Universitas Negeri Malang.

Tversky, A., \& Kahneman, D. (1991). Loss Aversion in Riskless Choice: A ReferenceDependent Model. Quarterly Journal of Economics , 1040-1061.

Thaler, R. H. (1987). Anomalies; The January Effect. Economic Perspective , 1 (1), $197-$ 201.

Thaler, R. H. (2016). Misbehaving. The Making of Behavioral Economics. Penguins Book.

Thaler, R. H., \& Sunstein, C. R. (2008). Nudge: Improving Decisions about Health, Wealth, and Happiness. Boston: Yale University Press.

Utomo, V. J., \& Herlambang, L. (2015). Efek Hari Libur Lebaran pada Emiten yang Terdaftar dalam ISSII Periode 2011-2013. Journal Ekonomi Syariah Teori dan Terapan , 2 (5), 372-386. 